\title{
The effects of endothelin-1 and $\mathrm{NG}^{\mathrm{G}}$-nitro-L-arginine methyl ester on regional haemodynamics in conscious rats with streptozotocin-induced diabetes mellitus
}

\author{
R.J. Kiff, ${ }^{1}$ S.M. Gardiner, A.M. Compton \& T. Bennett
}

Department of Physiology \& Pharmacology, University of Nottingham Medical School, Queen's Medical School, Nottingham NG7 2UH

1 Resting haemodynamic status and responses to endothelin-1 $\left(0.004,0.04,0.4 \mathrm{nmol} \mathrm{kg}^{-1}\right)$ and $\mathrm{N}^{\mathrm{G}}$-nitro$\mathrm{L}$-arginine methyl ester ( $\mathrm{L}-\mathrm{NAME}, 10 \mathrm{mg} \mathrm{kg}^{-1}$ ) were assessed in conscious, Wistar rats treated with streptozotocin (STZ) to induce diabetes mellitus, and in control animals treated with saline.

2 In the resting state, STZ-treated rats had a bradycardia relative to control animals $(291 \pm 13$ and $337 \pm 10$ beats $\min ^{-1}$, respectively), but mean arterial blood pressures were the same in the two groups (STZ-treated $109 \pm 3$; control $114 \pm 4 \mathrm{mmHg})$. However, the STZ-treated rats had raised renal $(105 \pm 9$ units) and mesenteric (114 \pm 16 units) vascular conductances and reduced hindquarters vascular conductance ( $26 \pm 4$ units) relative to control rats (renal, $80 \pm 6$; mesenteric, $75 \pm 7$; hindquarters, $37 \pm 3$ units).

3 Increasing doses of endothelin-1 caused similar, early falls and subsequent rises in mean arterial blood pressures in both groups of rats. Although there were initial hindquarters vasodilatations with endothelin1 that were not different in STZ-treated and control rats, there were subsequent renal and mesenteric vasoconstrictions that were greater in the former. Hence, the similar rises in mean arterial blood pressures must have been accompanied by a greater reduction in cardiac output in the STZ-treated rats.

4 L-NAME caused similar renal and mesenteric vasoconstrictions in control and STZ-treated rats, but there was a smaller pressor effect and an attenuated hindquarters vasoconstrictor response to L-NAME in STZ-treated rats.

5 Collectively, the results indicate that the resting renal and mesenteric vasodilatations in STZ-treated rats relative to control were probably not due to diminished vascular sensitivity to endogenous endothelin-1 or to enhanced sensitivity to, or production of, nitric oxide in these vascular beds. However, the relative hindquarters vasoconstriction in the resting state and the diminished hindquarters vasoconstrictor response to L-NAME in STZ-treated rats is consistent with diminished nitric oxide production in that vascular bed.

Keywords: Streptozotocin; endothelin-1; $N^{G}$-nitro-L-arginine-methyl ester (L-NAME); regional haemodynamics; diabetes mellitus

\section{Introduction}

It is known now that endothelial cells make important contributions to cardiovascular regulation through the release of vasoconstrictor and vasodilator factors (Furchgott, 1983). At present, the most potent endothelium-derived vasoconstrictor identified is the peptide, endothelin-1 (Yanagisawa et al., 1988), whereas the major vasodilator produced by endothelial cells is nitric oxide (Palmer et al., 1987; Hutchinson et al., 1987; Moncada \& Higgs, 1990). In vivo it is likely there is interplay between these factors since there is in vitro evidence that endothelin-1 stimulates the release of endotheliumderived relaxing factor (Miller et al., 1989; Warner et al., 1989) whereas the latter inhibits endothelin-1 release, in as much as antagonism of nitric oxide production disinhibits endothelin-1 release (Boulanger \& Lüscher, 1990).

Such interactions could contribute to the complex cardiovascular responses to administering exogenous endothelin-1 or manipulating nitric oxide production in vivo. For example, in conscious animals i.v. bolus injections of endothelin-1 have been shown to cause a biphasic arterial blood pressure and heart rate response. There is an initial transient fall in blood pressure, which is associated with a tachycardia, followed by a more sustained rise in blood pressure and bradycardia (Gardiner et al., 1989a; Madeddu et al., 1989; Mortensen \& Fink, 1990). The initial hypotension is associated with marked vasodilatations in the hindquarters and carotid vascular beds, whereas the subsequent hypertension is associated with vaso-

\footnotetext{
${ }^{1}$ Author for correspondence.
}

constrictions in renal, mesenteric, hindquarters and carotid vascular beds (Gardiner et al., 1989a).

In conscious rats, bolus injections of $\mathrm{N}^{\mathrm{G}}$-monomethyl-Larginine (L-NMMA) or $\mathrm{N}^{\mathrm{G}}$-nitro-L-arginine methyl ester (LNAME) also cause initial hindquarters vasodilatations and, thereafter, marked renal, mesenteric hindquarters and carotid vasoconstrictions, accompanied by hypertension (Gardiner $e t$ al., 1990c,d). Since L-NMMA and L-NAME both inhibit nitric oxide production (Palmer et al., 1988; Rees et al., 1990), then it is feasible that the similarity in the haemodynamic effects of endothelin-1, L-NMMA and L-NAME is due in part to the actions of the latter compounds being dependent on disinhibition of the release of endogenous endothelin-1 (Boulanger \& Lüscher, 1990).

The production of endothelin-1 and nitric oxide by endothelial cells and the interactions between these factors is likely to be abnormal in conditions in which endothelial cell function is disordered; one such condition is clinical diabetes mellitus (Porta et al., 1987; Stout, 1987; Jensen et al., 1989). Furthermore, studies on tissues taken from animals with experimental diabetes mellitus have indicated abnormalities of vascular function associated with disordered endotheliummediated responses, although the findings are contradictory (Oyama et al., 1986; Bhardwaj \& Moore, 1988; Harris \& Macleod, 1988). However, no comparative in vitro studies on tissues from normal rats and rats with experimental diabetes mellitus have used appropriately adjusted bathing media to control for the differences in the composition of the extracellular fluid of control and diabetic rats (Hebden et al., 1986), and hence this might be a source of confusion. This problem could 
be avoided by carrying out studies in vivo, but thus far there have been no investigations of regional haemodynamic status in conscious rats with experimental diabetes mellitus that have considered the possible consequences of endothelial cell dysfunction. So, in the present work we assessed regional haemodynamic status in conscious, unrestrained Wistar rats with diabetes mellitus induced by injection of streptozotocin (STZ), and compared these animals with saline-injected control rats. We found (see Results) that STZ-treated animals had resting renal and mesenteric vasodilatations, but a hindquarters vasoconstriction, relative to control rats. Therefore, we measured regional haemodynamic responses to increasing doses of endothelin-1 in both groups of animals and compared those responses to the effects of administering a maximal dose of L-NAME (Gardiner et al., 1990d).

\section{Methods}

Male Wistar rats (aged between 15-20 weeks and weighing $350-500 \mathrm{~g})$ were injected with either STZ $\left(70 \mathrm{mg} \mathrm{kg}^{-1}\right.$ in $0.9 \%$ $\mathrm{NaCl})$ or isotonic saline $(0.9 \% \mathrm{NaCl})$ intraperitoneally (i.p.) (Hebden et al., 1986; Tomlinson et al., 1989). Blood glucose levels were determined from a tail vein blood sample, 4 days after the STZ injection, by use of a Reflomat (Boehringer, Mannheim); those rats with blood glucose levels of greater than $12 \mathrm{mmoll}^{-1}$ were considered diabetic and were entered into the experiment.

Fourteen days after STZ or saline injection the rats were anaesthetized (sodium methohexitone $60 \mathrm{mg} \mathrm{kg}^{-1}$ i.p., supplemented as required) and miniaturized pulsed Doppler probes (Haywood et al., 1981) were sutured around the left renal and superior mesenteric arteries and the distal abdominal aorta (below the ileocaecal artery to measure hindquarters flow). The wires from the probes were secured to the body wall before being fed subcutaneously to the back of the neck and sutured in place. The animals received an intramuscular injection of ampicillin (Penbritin, Beecham, $7 \mathrm{mg} \mathrm{kg}^{-1}$ ) and were allowed to recover in their home cages (Gardiner et al., 1990d).

After a further 14 days the animals were re-anaesthetized (sodium methohexitone $40 \mathrm{mg} \mathrm{kg}^{-1}$ i.p., supplemented as required). The wires from the probes were soldered to a microconnector (Microtech Inc., Boothwyn, PA, U.S.A.). The right jugular vein was exposed and three venous catheters inserted. An intra-arterial catheter was inserted into the caudal artery and advanced up into the distal abdominal aorta. The catheters were all fed subcutaneously to the back of the neck. The microconnector was fixed to a harness worn by the rat and the catheters were fed through the harness and up a flexible spring, supported by a counter-weight to permit free movement of the animals. The animals were allowed to recover and were housed individually, with unlimited access to food and water (Gardiner et al., 1990d).

The following day the microconnector was linked to a pulsed Doppler flowmeter (VF-1 Crystal Biotech, Massachusetts, U.S.A.) modified to operate with a pulse repetition frequency of $125 \mathrm{kHz}$ (Gardiner et al., 1990b) and the arterial catheter was connected to a pressure transducer. Heart rate, phasic and mean blood pressure and phasic and mean Doppler shift signals were recorded continuously on a Gould ES 1000 recorder. Mean Doppler shift signals were taken as an index of flow (Haywood et al., 1981) and are referred to as such in the text hereafter. Vascular conductances were calculated by dividing the mean Doppler shift values by mean blood pressure (Gardiner et al., 1990d) and are expressed in arbitrary units (i.e. $\left.\left[\mathrm{kHz} \mathrm{mmHg}^{-1}\right) 10^{3}\right]$ ).

After a $30 \mathrm{~min}$ period of baseline recording each animal received three doses of endothelin- $1 \quad(0.004,0.04$ and $0.4 \mathrm{nmol} \mathrm{kg}^{-1}$ ) in ascending order, with at least $1 \mathrm{~h}$ between each dose. Measurements were made before and 10,14, 36 and $64 \mathrm{~s}$ after each endothelin-1 injection. These times were chosen to provide a full profile of the effects of endothelin-1.
At least $2 \mathrm{~h}$ after the last dose of endothelin-1, each animal received L-NAME at a dose of $10 \mathrm{mg} \mathrm{kg}^{-1}$. This dose was chosen because it produced maximal effects in other studies (Gardiner et al., 1990d). Measurements were made before L-NAME and at a time when the variables had reached a steady state (approximately $6 \mathrm{~min}$ after L-NAME injection).

Blood glucose levels (Reflomat) were determined from a cardiac puncture sample at the end of the experiment. All the STZ-treated rats had blood glucose levels in excess of $20 \mathrm{mmoll}^{-1}$ (the limit of detection of the Reflomat); the blood glucose concentration in the control animals was $5.8 \pm 3 \mathrm{mmoll}^{-1}$ (mean \pm s.e.mean; $\left.n=9\right)$.

\section{Data analysis}

Data analysis involved the non-parametric, Wilcoxon signed ranks paired test, and the non-parametric Mann-Whitney $U$ test for paired and unpaired data, respectively. $P<0.05$ was taken as significant.

\section{Drugs}

STZ (Sigma) was dissolved in isotonic saline $\left(47 \mathrm{mg} \mathrm{ml}^{-1}\right)$ and used immediately because of its instability. Endothelin-1 (Peptide Institute, Osaka, Japan, obtained through Scientific Marketing Associates, London) was dissolved in isotonic saline containing $1 \%$ bovine serum albumin and L-NAME (Sigma) was dissolved in isotonic saline.

Both endothelin-1 and L-NAME were administered in $0.1 \mathrm{ml}$ boluses and the catheter flushed with $0.15 \mathrm{ml}$ isotonic saline.

\section{Results}

\section{Resting conditions}

Under resting conditions, STZ-treated rats $(n=11)$ had significantly $(P<0.05)$ lower heart rates than control rats $(n=9)$, but there was no difference between the mean blood pressures of the two groups (Table 1). Renal and mesenteric blood flows were not significantly different in the control and diabetic rats, but hindquarters blood flow was significantly $(P<0.05)$ reduced in the latter (Table 1$)$. Calculated vascular conductances showed significant vasodilatation in the renal and mesenteric vascular beds of the diabetic animals $(P<0.05)$ and a significant hindquarters vasoconstriction $(P<0.05$ : Table 1) compared to controls.

\section{Cardiovascular responses to endothelin-1}

Blood pressure and heart rate The lowest dose of endothelin$1\left(0.004 \mathrm{nmol} \mathrm{kg}^{-1}\right)$ had no significant effect on blood pres-

Table 1 Cardiovascular variables under basal conditions in conscious, unrestrained, control and diabetic Wistar rats

\begin{tabular}{lcc}
\hline & $\begin{array}{c}\text { Control } \\
(\mathrm{n}=9)\end{array}$ & $\begin{array}{c}\text { Diabetic } \\
(n=11)\end{array}$ \\
$\begin{array}{l}\left.\text { Heart rate (beats } \min ^{-1}\right) \\
\text { Mean arterial blood } \\
\text { pressure (mmHg) }\end{array}$ & $\begin{array}{l}337 \pm 10 \\
\text { Doppler shift (kHz) }\end{array}$ & $291 \pm 13^{*}$ \\
$\quad$ Renal & $9.2 \pm 0.8$ & $109 \pm 3$ \\
Mesenteric & $8.5 \pm 0.7$ & $11.5 \pm 1.0$ \\
$\quad$ Hindquarters & $4.2 \pm 0.4$ & $2.9 \pm 0.4^{*}$ \\
Vascular conductance & & \\
$\quad$ (arbitrary units) & & \\
Renal & $80 \pm 6$ & $105 \pm 9^{*}$ \\
Mesenteric & $75 \pm 7$ & $114 \pm 16^{*}$ \\
Hindquarters & $37 \pm 3$ & $26 \pm 4^{*}$
\end{tabular}

Values are mean \pm s.e.mean.

$* P<0.05$ Diabetic versus control, Mann-Whitney U test. 


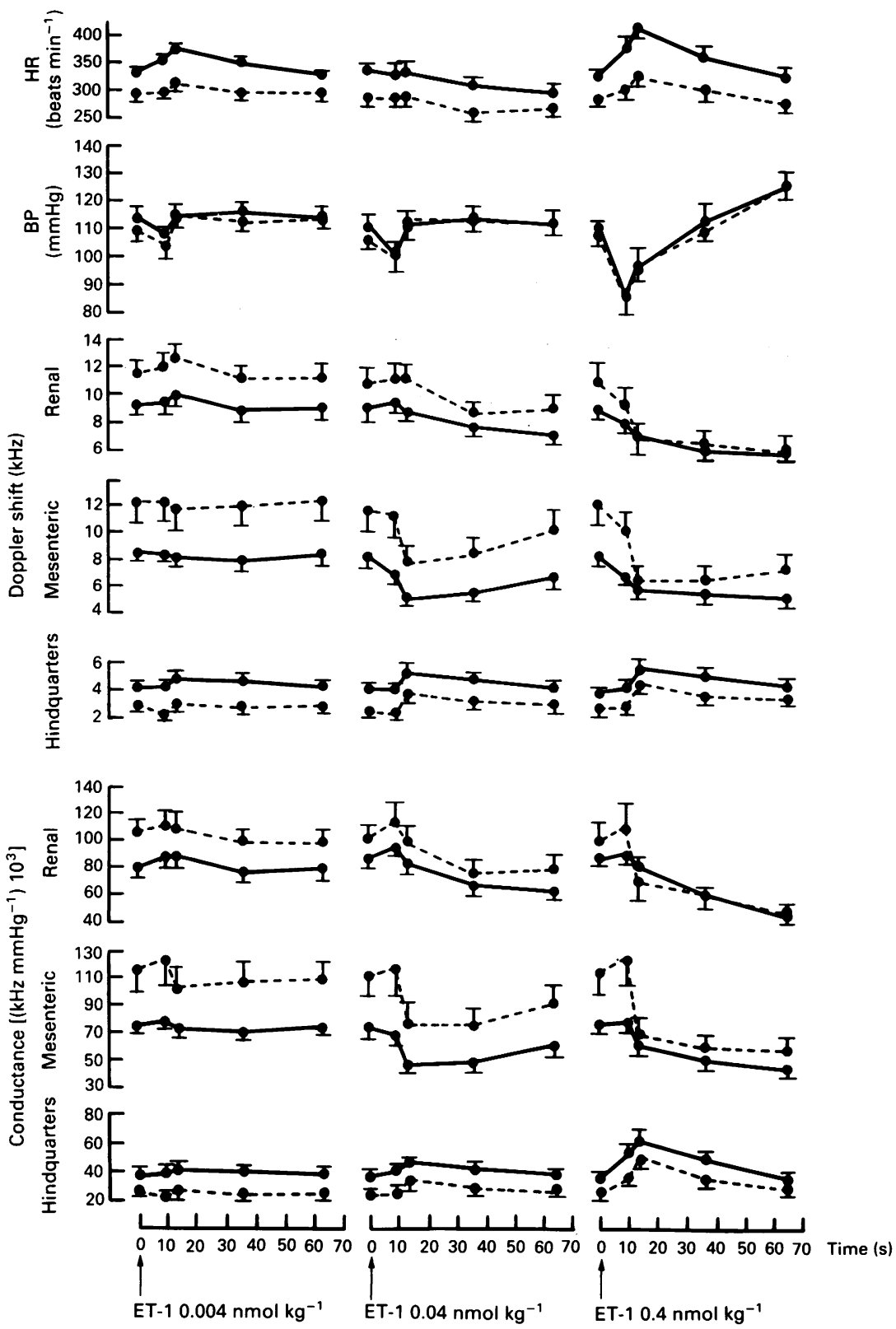

Figure 1 Changes in heart rate (HR), mean arterial blood pressure (BP), mean Doppler shift (blood flow) and vascular conductances of conscious, unrestrained, control (solid line) and streptozotocin (STZ)-treated (dotted line), Wistar rats to three i.v. bolus injections of endothelin-1 (ET-1). Values are the mean, and the bars are the s.e.mean; control $n=9, \mathrm{STZ}_{n}=11$. For clarity all the statistics are given in the text.

sure, and caused only a modest and transient tachycardia in both groups (Figure 1).

The $0.04 \mathrm{nmol} \mathrm{kg}^{-1}$ dose of endothelin-1 caused similar significant, but transient falls in blood pressure in both groups (control $-12 \pm 4 \mathrm{mmHg}$; STZ $-6 \pm 2 \mathrm{mmHg}, P<0.05$ : Figure 1); thereafter blood pressure returned to baseline in the control group whereas it rose modestly above baseline in the STZ group $(+8 \pm 2 \mathrm{mmHg}, P<0.05$ : Figure 1$)$. There were no significant changes in heart rate in either group.

After the highest dose of endothelin-1 $\left(0.4 \mathrm{nmol} \mathrm{kg}^{-1}\right)$ there were marked, transient hypotensive responses in both groups (control $-25 \mathrm{mmHg}$; STZ $-24 \pm 3 \mathrm{mmHg}, P<0.05$ : Figure 1) followed by rises in blood pressure above baseline (control $+16 \pm 4 \mathrm{mmHg}$; STZ $+18 \pm 3 \mathrm{mmHg}, P<0.05$ : Figure 1 ). The hypotensive response to endothelin-1 was associated with a greater $(P<0.05)$ increase in heart rate in the control than in the STZ-treated group (Figure 1).

Renal flow and vascular conductance In both groups of rats, endothelin-1 caused dose-related falls in renal flows and vascular conductances (significant for the 0.04 and $0.4 \mathrm{nmol} \mathrm{kg}^{-1}$ doses: Figure 1). After the highest dose of endothelin-1 the maximum fall in renal vascular conductance in the STZ-treated group ( $-52 \pm 7$ units) was significantly $(P<0.05)$ greater than in the control group $(-35 \pm 4$ units), such that the absolute vascular conductances in the groups were then the same (Figure 1).

Mesenteric flow and vascular conductance There were doserelated falls in mesenteric flow and vascular conductance in both groups which were significant following the 0.04 and $0.4 \mathrm{nmol} \mathrm{kg}^{-1}$ doses of endothelin-1 (Figure 1). In the STZtreated group the maximum fall in mesenteric flow following the $0.4 \mathrm{nmol} \mathrm{kg}^{-1}$ dose $(-6 \pm 1 \mathrm{kHz})$ and the maximum falls in mesenteric vascular conductance following the 0.04 and $0.4 \mathrm{nmol} \mathrm{kg} \mathrm{k}^{-1}$ doses $(-40 \pm 8$ and $-55 \pm 9$ units, respectively) were greater than the corresponding changes seen in the control group $(-3 \pm 1 \mathrm{kHz} ;-25 \pm 4$ units; $-31 \pm 6$ units, respectively, all $P<0.05$ ). Thus, following the $0.4 \mathrm{nmol} \mathrm{kg}{ }^{-1}$ dose of endothelin-1 the absolute mesenteric 
Table 2 Comparison of the haemodynamic effects of $\mathrm{N}^{\mathrm{G}}$ nitro-L-arginine methyl ester (L-NAME) $\left(10 \mathrm{mg} \mathrm{kg}^{-1}\right)$ in conscious, unrestrained, control and diabetic Wistar rats

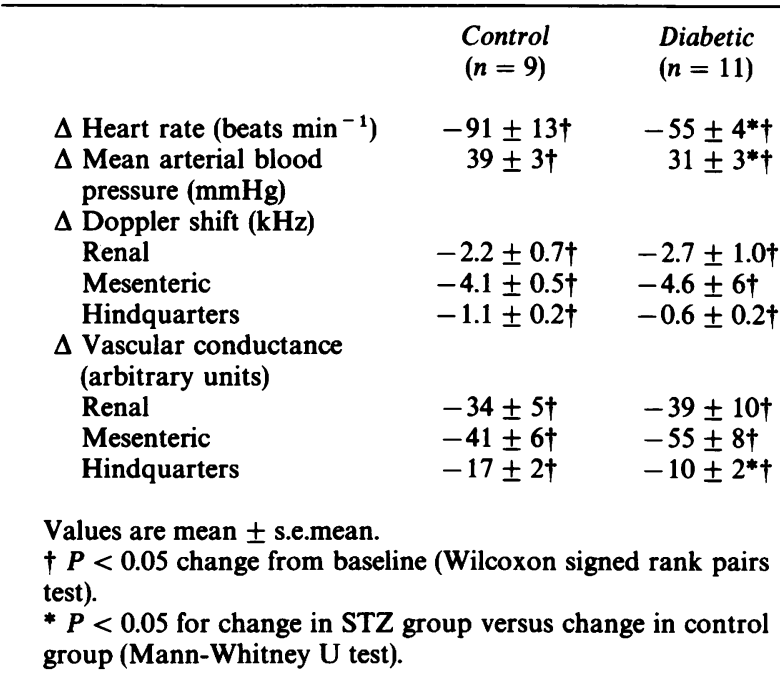

vascular conductances were the same in control and STZtreated rats (Figure 1).

Hindquarters flow and vascular conductance The lowest dose of endothelin-1 had no significant effect on hindquarters flow or vascular conductance in either group. Endothelin-1 $\left(0.04 \mathrm{nmol} \mathrm{kg}{ }^{-1}\right)$ caused similar rises in hindquarters flow in both groups, but this was associated with a significant $(P<0.05)$ increase in hindquarters conductance in the control group only (Figure 1). The highest dose of endothelin-1 $\left(0.4 \mathrm{nmol} \mathrm{kg}^{-1}\right)$ caused similar, significant $(P<0.05)$ increases in hindquarters flow and vascular conductance in both groups (Figure 1).

\section{Cardiovascular responses to $N^{G}$-nitro-L-arginine methyl ester}

L-NAME (10 $\mathrm{mg} \mathrm{kg}^{-1}$ ) caused an increase in blood pressure which was associated with decrease in heart rate and renal, mesenteric and hindquarters flow and vascular conductance in both groups. However, the STZ-treated group demonstrated a significantly smaller increase in blood pressure $(P<0.05)$ and decreases in heart rate $(P<0.05)$ and hindquarters vascular conductance $(P<0.05)$ than the control group (Table 2$)$.

\section{Discussion}

Under resting conditions the conscious, STZ-treated Wistar rats in the present study had a bradycardia, with a normal mean blood pressure. Bradycardia following STZ treatment has been reported by several authors (e.g. Stuesse et al., 1982; Carbonell et al., 1987; Hebden et al., 1987a; Tomlinson et al., $1989 ;$ 1990). Tomlinson et al. (1990) have shown that Brattleboro (i.e. vasopressin-deficient) rats have a bradycardia following treatment with STZ. Thus, elevated circulating vasopressin levels causing coronary vasoconstriction (Boyle \& Segel, 1986), or interactions between vasopressin and cardiac neural control (Osborn et al., 1987), are not likely to be responsible for the bradycardia. Clearly, activation of vagal mechanisms (Kofo-Abayomi \& Lucas, 1987) and/or inhibition of sympathetic efferent input to the heart, independent of vasopressin, could explain the slow sinus rate following treatment with STZ, but the bradycardia has been found to persist following ganglion blockade (Hebden et al., 1987a; Tomlinson et al., 1990). This observation indicates that myocardial factors (Savarese \& Berkowitz, 1979; Dillman, 1982; Ganguly et al., 1983; Sundaresan et al., 1984) may be responsible for the bradycardia in STZ-treated rats. Such factors could also account for the present findings of diminished tachycardia or bradycardia to endothelin-1 and L-NAME, respectively, in STZ-treated rats (although the chronotropic effects of endothelin-1 (Gardiner et al., 1990a) and L-NAME (unpublished observations) are reflex in origin). However, this cannot be the full explanation of the present findings, since cardiac reflex responses to the pressor effects of vasopressin, angiotensin II or methoxamine are not reduced in STZtreated, Wistar rats (Hebden et al., 1987b).

Several studies have reported on resting arterial blood pressure following STZ treatment; some have shown diabetic rats are hypertensive (Kawashima et al., 1978; Bunag et al., 1982; Funakawa et al., 1983), whereas others have found they are normotensive (Rodgers, 1986; Yamamoto, 1988) or hypotensive (Kohler et al., 1980; Hebden et al., 1987a; Kusaka et al., 1987; Tomlinson et al., 1989; 1990). The difference between the results from this present study and our earlier studies, in which we reported hypotension in diabetic rats (Hebden et al. 1987a,b; Tomlinson et al., 1989; 1990), is that previously both systolic and diastolic blood pressures were recorded, and it was systolic pressure which was consistently reduced (Hebden et al., 1987a; Tomlinson et al., 1989). In the present work we also observed a reduction in systolic blood pressure following STZ treatment (data not shown), but we measured electronically-derived mean blood pressure (in order to calculate vascular conductances) and this was not reduced because in the bradycardic, STZ-treated rats the pressure wave form is broader than in control animals.

Although mean blood pressures were similar in STZ-treated and control rats, their haemodynamic profiles were different, with vasodilatation in the renal and mesenteric vascular beds and vasoconstriction in the hindquarters vascular bed of the diabetic rats, relative to the control animals. There is a marked hypertrophy of the kidney and gastrointestinal tract following treatment with STZ (Caspary, 1973; Christiansen et $a l ., 1981)$ and it is feasible that associated increases in vascularity contribute to the increases in renal and mesenteric vascular conductances (Lucas \& Foy, 1977; Christiansen et al., 1981; Hill \& Larkins, 1989). That the mesenteric vasodilatation might be accounted for partly by hypertrophy of the intestine was shown by Hill \& Larkins (1989) who found the hyperaemia could be attenuated by underfeeding rats treated with STZ. However, other factors must be involved since Korthuis et al. (1987) found that cross-perfusion of jejunum-ileum preparations from control rats with blood from STZ-treated rats caused vasodilatation of a similar degree to that seen in the latter in vivo. Subsequent studies showed the intestinal hyperaemia in STZ-treated rats was partly due to hyperglucagonaemia, since it was significantly reduced by a specific antiserum to glucagon (Yrle et al., 1988). However, Yrle et al. (1988) suggested other factors, including plasma osmolality and plasma glucose concentration, could have contributed to the intestinal hyperaemia in STZ-treated rats. Factors such as these could have contributed also to the renal vasodilatation observed in the present study. Although renal vasodilatation in STZ-treated rats has been observed previously (e.g. Lucas \& Foy, 1977; Jensen et al., 1981) it has not been found in all studies (e.g. Ha \& Dunham, 1987; Yrle et al., 1988). However, in many previous investigations measurements were made under anaesthesia (which compromises renal perfusion) so the results cannot be extrapolated to the conscious state.

In the present study, although there were significant elevations in resting conductances in renal and mesenteric vascular beds in STZ-treated, compared to control rats, the former showed more marked vasoconstrictions to endothelin-1, such that following the highest dose of the peptide there were no differences between renal or between mesenteric vascular conductances in the two groups of rats. These results indicate that the resting renal and mesenteric vasodilatations in STZtreated rats were probably not due to diminished sensitivity to endogenous endothelin-1, but they do not preclude the possibility that endothelial cells in STZ-treated rats produce less 
endothelin-1 than normal. However, it has been reported that circulating levels of endothelin-1 are elevated in clinical diabetes mellitus (Takahashi et al., 1989), and that elevated glucose levels enhance endothelin-1 secretion by cultured endothelial cells (Yamauchi et al., 1990).

Following administration of L-NAME the renal and the mesenteric vasoconstrictions were similar in STZ-treated and control rats. Hence, it appears that the resting vasodilatations in the renal and mesenteric vascular beds in the STZ-treated rats were probably not due to increased sensitivity to, and/or increased production of, nitric oxide. In addition, the present results with endothelin-1 and L-NAME indicate that the renal and mesenteric vasodilatations in STZ-treated rats were probably not due to enhanced endothelial nitric oxide production inhibiting release of endogenous endothelin-1 (Boulanger \& Lüscher, 1990).

The resting hindquarters vasoconstrictions in the STZtreated rats in the present study is consistent with the findings of others (Hill \& Larkins, 1989) showing reduced skin and skeletal muscle blood flow in diabetic rats. Following STZtreatment there is atrophy of skeletal muscle (Feng et al., 1990) and hence the reduced hindquarters flow and vascular conductance observed in the present study could have been simply a reflection of reduced vascularity in the wasted muscle. However, the finding that the pressor and hindquarters vasoconstrictor response to L-NAME were attenuated in STZ-treated, compared to control, rats raises the interesting possibility that endothelial cell nitric oxide production, and/or vascular sensitivity to nitric oxide, is diminished specifically in the hindquarters, and this is responsible for the diminished pressor effect of L-NAME. One possible explanation for such a selective endothelial abnormality (i.e. present in the hindquarters but not in the renal or mesenteric vascular beds) is that, following STZ treatment, skeletal muscle glutamine synthesis is enhanced (Feng et al., 1990), and elevated glutamine levels in the environs of the endothelial cells in the hindquar-

\section{References}

BHARDWAJ, R. \& MOORE, P.K. (1988). Increased vasodilator response to acetylcholine of renal blood vessels from diabetic rats. J. Pharm. Pharmacol., 40, 739-742.

BOULANGER, C. \& LUSCHER, T.F. (1990). Release of endothelin from the porcine aorta. J. Clin. Invest., 85, 587-590.

BOYLE, W.A. \& SEGEL, L.D. (1986). Direct cardiac effects of vasopressin and their reversal by a vascular antagonist. Am. J. Physiol., 251, H734-H741.

BUNAG, R.D., TOMITA, T. \& SASAKI, S. (1982). Streptozotocin diabetic rats are hypertensive despite reduced hypothalamic responsiveness. Hypertension, 4, 556-565.

CARBONELL, L.F., SALOM, M.G., GARCIA-ESTAN, J., SALAZAR, F.J. UBEDA, M. \& QUESADA, T. (1987). Hemodynamic alterations in chronically conscious unrestrained diabetic rats. Am. J. Physiol. 252, H900-H905.

CASPARY, W.F. (1973). Effect of insulin and experimental diabetes mellitus on the digestive-absorptive function of the small intestine. Digestion, 9, 248-263.

CHRISTIANSEN, J., GAMMELGAARD, J., FRANDSEN, M. \& PARVING H.H. (1981). Increased kidney size, glomerular filtration rate and renal plasma flow in short-term insulin-dependent diabetics. Diabetologia, 20, 451-456.

DILLMAN, W.H. (1982). Influence of thyroid hormone administration on myosin ATPase activity and myosin isoenzyme distribution in the heart of diabetic rats. Metabolism, 31, 199-204.

FENG, B., BANNER, C. \& MAX, S.R. (1990). Effect of diabetes on glutamine synthetase expression in rat skeletal muscles. Am. J. Physiol., 258, E762-E766.

FUNAKAWA, S., OKAHARA, T., IMANISHI, M., KOMORI, T., YAMAMOTO, K. \& TOCHINO, Y. (1983). Renin-angiotensin system and prostacyclin biosynthesis in streptozotocin diabetic rats. Eur. J. Pharmacol., 94, 27-33.

FURCHGOTT, R.F. (1983). Role of endothelium in responses of vascular smooth muscle. Circ. Res., 53, 557-573.

GANGULY, P.K. PIERCE, G.N., DHALLA, K.S. \& DHALLA, N.S. (1983). Defective sarcoplasmic reticular calcium transport in diabetic cardiomyopathy. Am. J. Physiol., 244, E528-E535. ters vascular bed inhibits the generation of nitric oxide from L-arginine (Hecker et al., 1990). If this is the case then it is particularly noteworthy that the hindquarters vasodilator response to endothelin-1 was not diminished in STZ-treated rats, since Whittle et al. (1989) have claimed that inhibiting nitric oxide production with L-NMMA antagonizes the vasodilator effects of endothelin-1. However, our proposition that the hindquarters production of nitric oxide could be diminished although the vasodilator response to endothelin-1 was intact is consistent with our previous finding that neither L-NMMA nor L-NAME inhibit the hindquarters vasodilator response to endothelin-1 (Gardiner et al., 1989b; 1990d).

Whatever the explanation of the initial hypotensive response to endothelin-1 it is clear that this effect was similar in STZ-treated and control rats. Furthermore, the subsequent rise in mean arterial blood pressure was the same in both groups. Since the STZ-treated animals showed more marked renal and mesenteric vasoconstrictor responses to endothelin1 than did control rats, then the accompanying fall in cardiac output (Gardiner et al., 1990e) in the former must have been greater than in the latter. Elsewhere we have shown that the reduction in cardiac output during the hypertension elicited by endothelin-1 is independent of reflex mechanisms (Gardiner et al., 1990a), and hence is likely to be due to the increase in afterload and/or to direct cardiac effects of the peptide. However, Nayler et al. (1989) have shown a decreased density of cardiac binding sites for endothelin-1 in STZtreated rats, and together with the present results, this indicates a greater fall in cardiac output in STZ-treated rats during the hypertensive response to endothelin-1 would be most likely due to the greater rise in afterload. Direct assessment of cardiac haemodynamic status and the cardiac response to L-NAME (Gardiner et al., 1990d) in STZ-treated rats will provide quantitative information on this point.

This work was supported by Wellcome Research Laboratories.

GARDINER, S.M., COMPTON, A.M. \& BENNETT, T. (1989a). Regional hemodynamic effects of endothelin-1 in conscious, unrestrained, Wistar rats. J. Cardiovasc. Pharmacol., 13, Suppl. 5, S202-S204.

GARDINER, S.M., COMPTON, A.M., BENNETT, T., PALMER, R.M.J. \& MONCADA, S. (1989b). $N^{G}$-monomethyl-L-arginine does not inhibit the hindquarters vasodilator action of endothelin-1 in conscious rats. Eur. J. Pharmacol., 171, 237-240.

GARDINER, S.M., COMPTON, A.M. \& BENNETT, T. (1990a). Effects of endothelin-1 on cardiac output in conscious rats in the absence and presence of cardiac autonomic blockade. Eur. J. Pharmacol., 183, 2232-2233.

GARDINER, S.M., COMPTON, A.M., BENNETT, T. \& HARTLEY, C.J. (1990b). Can pulsed Doppler technique measure changes in aortic blood flow in conscious rats? Am. J. Physiol., 259, H448-H456.

GARDINER, S.M., COMPTON, A.M., BENNETT, T., PALMER, R.M.J. \& MONCADA, S. (1990c). Control of regional blood flow by endothelium-derived nitric oxide. Hypertension, 15, 486-492.

GARDINER, SM COMPTON, AM KEMP, PA \& BENNETT, T (1990d). Regional and cardiac haemodynamic effects of $\mathrm{N}^{\mathrm{G}}$-nitroL-arginine methyl ester in conscious. Long Evans rats. Br. J. Pharmacol., 101, 625-631.

GARDINER, S.M., COMPTON, A.M., KEMP, P.A. \& BENNETT, T $(1990 \mathrm{e})$. Cardiac output effects of endothelin-1, -2 and -3 and sarafotoxin S6b in conscious rats. J. Auton. Nerv. Syst., 30, 143-148.

HA, H. \& DUNHAM, E.W. (1987). Limited capacity for renal vasodilatation in anaesthetized diabetic rats. Am. J. Physiol., 253, H845H855.

HARRIS, K.H. \& MACLEOD, M. (1988). Influence of the endothelium on contractile responses of arteries from diabetic rats. Eur. $J$. Pharmacol, 153, 53-64.

HAYWOOD, J.R., SHAFFER, R.A., FASTENOW, C., FINK, G.D. \& BRODY, M.J. (1981). Regional blood flow measurement with pulsed Doppler flowmeter in conscious rats. Am. J. Physiol., 241, H273H278.

HEBDEN, R.A., GARDINER, S.M., BENNETT, T. \& MACDONALD, I.A (1986). The influence of streptozotocin-induced diabetes mellitus on fluid and electrolyte handling in rats. Clin. Sci., 70, 111-117. 
HEBDEN, R.A., BENNETT, T. \& GARDINER, S.M. (1987a). Abnormal blood pressure recovery during ganglion blockade in diabetic rats. Am. J. Physiol., 252, R102-R108.

HEBDEN, R.A., BENNETT, T. \& GARDINER, S.M. (1987b). Pressor sensitivities to vasopressin, angiotensin II, or methoxamine in diabetic rats. Am. J. Physiol., 253, R726-R734.

HECKER, M., MITCHELL, J.A., SWIERKOSZ, T.A., SESSA, W.C. \& VANE, J.R. (1990). Inhibition by L-glutamine of the release of endothelium-derived relaxing factor from cultured endothelial cells. Br. J. Pharmacol., 101, 237-239.

HILL, M.A. \& LARKINS, R.G. (1989). Alterations in distribution of cardiac output in experimental diabetes in rats. Am. J. Physiol., 257, H571-H580.

HUTCHINSON, P.J.A., PALMER, R.M.J. \& MONCADA, S. (1987). Comparative pharmacology of EDRF and nitric oxide on vascular strips. Eur. J. Pharmacol., 141, 445-451.

JENSEN, P.K., CHRISTIANSEN, J., STEVEN, K. \& PARVING, H.H. (1981). Renal function in streptozotocin-diabetic rats. Diabetologia, 21, 409-414.

JENSEN, T., BJERRE-KNUDSEN, J., FELDT-RASMUSSEN, B. \& DECKERT, T. (1989). Features of endothelial dysfunction in early diabetic nephropathy. Lancet, i, 461-463.

KAWASHIMA, H., IGARASHI, T., NAKAJIMA, Y., AKIYAMA, Y., USUKI, K. \& OHTAKE, S. (1978). Chronic hypertension induced by streptozotocin in rats. Naunyn-Schmiedebergs Arch. Pharmacol., 305, 123126.

KOFO-ABAYOMI, A. \& LUCAS, P.D. (1987). Muscarinic receptor density is reduced in diabetic rat atria, an effect prevented by the aldose reductase inhibitor, Statil. J. Pharm. Pharmacol., 39, 1019 1021.

KOHLER, L., BIOLLET, N., LUTHI, P., ATKINSON, J. \& PETERSHAEFELI, L. (1980). Influence of streptozotocin-induced diabetes on blood pressure and on renin formation and release. NaunynSchmiedebergs Arch. Pharmacol., 313, 257-261.

KORTHUIS, R.J., BENOIT, J.N., KVIETYS, P.R., LAUGHLIN, M.H., TAYLOR, A.E. \& GRANGER, D.N. (1987). Intestinal hyperemia in experimental diabetes mellitus. Am. J. Physiol., 253, G26-G32.

KUSAKA, M., KISHI, K. \& SOKABE, H. (1987). Does so-called streptozotocin hypertension exist in rats? Hypertension, 10, 517-521.

LUCAS, P.D. \& FOY, J.M. (1977). Effects of experimental diabetes and genetic obesity on regional blood flow in the rat. Diabetes, 26, 786-792.

MADEDDU, P., TROFFA, C., GLOPRIOSO, N., PAZZOLA, A., SORO, A., MANUNTA, P., TONOLO, G., DEMONTIS, M.P., VARONI, M.V. \& ANANIA, V. (1989). Effect of endothelin on regional hemodynamics and renal function in awake normotensive rats. J. Cardiovasc. Pharmacol., 14, 818-825.

MILLER, V.M., KOMORI, K., BURNETT, J.C. \& VANHOUTTE, P.M (1989). Differential sensitivity to endothelin in canine arteries and veins. Am. J. Physiol., 257, H1127-H1131.

MONCADA, S. \& HIGGS, E.A. (1990). Nitric Oxide from L-Arginine: $A$ Bioregulatory System. Amsterdam: Excerpta Medica.

MORTENSEN, L.H. \& FINK, G.D. (1990). Hemodynamic effect of human and rat endothelin administration into conscious rats. Am. J. Physiol., 258, H362-H368.

NAYLER, W.G., LIU, J., PANAGIOTOPOULOS, S. \& CASLEY, D.J. (1989) Streptozotocin-induced diabetes reduced the density of $\left[{ }^{125} \mathrm{I}\right]-$ endothelin-binding sites in rat cardiac membranes. Br. J. Pharmacol., 97, 993-995.

OSBORN, J.W., SKELETON, M.M. \& COWLEY, A.W. (1987). Haemodynamic effects of vasopressin compared with angiotensin II in conscious rats. Am. J. Physiol., 252, H628-H637.
OYAMA, Y., KAWASAKI, H., HATTORI, Y. \& KANNO, M. (1986). Attenuation of endothelium-dependent relaxation in aorta from diabetic rats. Eur. J. Pharmacol., 132, 75-78.

PALMER, R.M.J., ASHTON, D.S. \& MONCADA, S. (1988). Vascular endothelial cells synthesize nitric oxide from L-arginine. Nature, 333, $664-667$.

PALMER, R.M.J., FERRIGE, A.G. \& MONCADA, S. (1987). Nitric oxide release accounts for the biological activity of endothelium-derived relaxing factor. Nature, 327, 524-526.

PORTA, M., LA SELVA, M., MOLINATTI, P. \& MOLINATTI, G.M. (1987). Endothelial cell function in diabetic microangiopathy. Diabetologia, 30, 601-609.

REES, D.D., PALMER, R.M.J., SCHULTZ, R., HODSON, H.F. \& MONCADA, S. (1990). Characterization of three inhibitors of endothelial nitric oxide synthase in vitro, and in vivo. Br.J. Pharmacol., 101, 746-752.

RODGERS, R.L. (1986). Depressor effect of diabetes in the spontaneously hypertensive rat: associated changes in heart performance. Can. J. Physiol. Pharmacol., 64, 1177-1184.

SAVARESE, J.J. \& BERKOWITZ, B.A. (1979). $\beta$-Adrenergic receptor decrease in diabetic rat hearts. Life Sci., 25, 2075-2078.

STOUT, R.W. (1987). The endothelial cell in diabetes. Front. Diabetes, 8, 116-124.

STUESSE, S.L., WALLICK, D.W. \& MACE, S. (1982). Vagal control of heart period in alloxan diabetic rats. Life Sci., 31, 393-398.

SUNDARESAN, P.R., SHARMA, V.K., GINGOLD, S.I. \& BANERJEE, S.P. (1984). Decreased $\beta$-adrenergic receptors in rat heart in streptozotocin-induced diabetes: role of thyroid hormones. Endocrinology, 114, 1358-1368.

TAKAHASHI, K., GHATEI, M.A., LAM, H.C., O'HALLORAN, D. \& BLOOM, S.R. (1989). Elevated plasma endothelin in diabetes mellitus. Regul. Pept., 25, 85.

TOMLINSON, K.C., GARDINER, S.M. \& BENNETT, T. (1989). Diabetes mellitus in Brattleboro rats: cardiovascular, fluid, and electrolyte status. Am. J. Physiol., 256, R1279-R1285.

TOMLINSON, K.C., GARDINER, S.M. \& BENNETT, T. (1990). Blood pressure in streptozotocin-treated Brattleboro and Long Evans rats. Am. J. Physiol., 258, R852-R859.

WARNER, T.D, MITCHELL, J.A, DE NUCCI, G. \& VANE, J.R. (1989) Endothelin-1 and endothelin-3 release EDRF from isolated perfused arterial vessels of the rat and rabbit. J. Cardiovasc. Pharmacol., 13, suppl. 5, S85-S88.

WHITTLE, B.J.R., LOPEZ-BELMONTE, J. \& REES, D.D. (1989). Modulation of the vasodepressor actions of acetylcholine, bradykinin, substance $P$ and endothelin in the rat by a specific inhibitor of nitric oxide formation. Br. J. Pharmacol., 98, 646-652.

YAMAMOTO, J. (1988). Blood pressure and metabolic effects of streptozotocin in Wistar-Kyoto and spontaneously hypertensive rats. Clin. Exp. Hypertens. [A], A10, 1065-1083.

YAMAUCHI, T., OHNAKA, K., TAKAYANAGI, R., UMEDA, F. \& NAWATA, H. (1990). Enhanced secretion of endothelin-1 by elevated glucose levels from cultured bovine aortic endothelial cells. FEBS Lett., 267, 16-18.

YANAGISAWA, M., KURIHARA, H., KIMURA, S., TOMOBE, Y., KOBAYASHI, M., MITSUI, Y., YAZAKI, Y., GOTO, K. \& MASAKI, T. (1988). A novel potent vasoconstrictor peptide produced by vascular endothelial cells. Nature, 332, 411-415.

YRLE, L.F., SMITH, K.J., BENOIT, J.N., GRANGER, N. \& KORTHUIS, J. (1988). Role of glucagon in intestinal hyperemia associated with early experimental diabetes mellitus. Am. J. Physiol., 255, G542G546. 